\title{
Parada Cardiorrespiratória em Unidade de Internação Cirúrgica: tecnologia educativa para sistematizar ações de enfermagem
}

\author{
Cardiopulmonary Arrest in a Surgical Inpatient Unit: educational technology to systematize \\ nursing actions
}

Parada Cardiopulmonar en una Unidad Quirúrgica de Hospitalización: tecnología educativa para sistematizar las acciones de enfermeira

Rosivalda Ferreira de Oliveira ORCID: https://orcid.org/0000-0003-2444-8259

Universidade de São Paulo, Brasil

E-mail: enf.rosa.oliveira@gmail.com Alex Miranda Franco

ORCID: https://orcid.org/0000-0002-9522-3607 Universidade do Estado do Pará, Brasil E-mail: enf.alexfranco@yahoo.com.br Alzinei Simor

ORCID: https://orcid.org/0000-0002-3848-5467 Universidade do Estado do Pará, Brasil E-mail: alzineisimor.enfo@gmail.com

Clarissa Porfírio Mendes

ORCID: https://orcid.org/0000-0001-6488-718X Universidade do Estado do Pará, Brasil E-mail: clarissapmendes@aluno.uepa.br

Gabriela de Nazaré e Silva Dias

ORCID: https://orcid.org/0000-0002-9476-0718 Universidade do Estado do Pará, Brasil E-mail: enfgabrieladias@gmail.com

Danielle Casseb Guimarães

ORCID: https://orcid.org/0000-0002-5183-8888 Universidade do Estado do Pará, Brasil E-mail: dany.casseb@gmail.com

Gracilene Wanzeler Moia

ORCID: https://orcid.org/0000-0002-6677-3570

Universidade de São Paulo, Brasil

E-mail: lenemoia@hotmail.com

Maria Madalena Castro Souto

ORCID: https://orcid.org/0000-0002-8869-5921

Universidade de São Paulo, Brasil

E-mail: msouto777@gmail.com

Matheus Almeida Ramalho

ORCID: https://orcid.org/0000-0002-5607-1313

Universidade Federal de Jataí, Brasil

E-mail: Matheusramalho@discente.ufg.br 


\title{
Resumo
}

Objetivo: produzir uma tecnologia assistencial para a equipe de enfermagem para detecção de PCR e início precoce de manobras de RCP. Metodologia: Trata-se de um estudo metodológico, desenvolvido em três etapas: Etapa 1 Definição do escopo, realizado em um hospital credenciado como Centro de Alta Complexidade em Oncologia. A pesquisa se desenvolveu com enfermeiros, enfermeiros residentes e técnicos de enfermagem, Etapa 2 - Levantamento bibliográfico - demonstrou uma escassez de produções acerca do tema abordado, o que justifica a criação do instrumento descrito neste estudo e Etapa 3 - Desenvolvimento - Construiu-se o fluxograma. Resultado: Obteve-se respostas permitindo a comparação antes e depois da aplicação de um instrumento de coleta criado pelos próprios autores e que propiciou a criação da tecnologia. Conclusão: A criação do fluxograma como tecnologia assistencial para sistematizar ações de enfermagem na clínica, possibilitou oferecer de forma clara e concisa a assistência no local, com ações de enfermagem para aumentar a sobrevida de pacientes vítimas de PCR.

Palavras-chave: Parada cardíaca; Reanimação cardiopulmonar; Enfermagem; Cuidados para prolongar a vida.

\begin{abstract}
Objective: to produce an assistive technology for the nursing team for detection of CPA and early initiation of CPR maneuvers. Methodology: This is a methodological study, developed in three stages: Step 1 - Definition of the scope, carried out in a hospital accredited as a Center for High Complexity in Oncology. The research was carried out with nurses, resident nurses and nursing technicians, Step 2 - Bibliographic survey - showed a shortage of productions on the topic addressed, which justifies the creation of the instrument described in this study and Step 3 - Development The flowchart. Result: Answers were obtained allowing for comparison before and after the application of a collection instrument created by the authors themselves and which led to the creation of the technology. Conclusion: The creation of the flowchart as an assistive technology to systematize nursing actions in the clinic, made it possible to offer on-site assistance in a clear and concise manner, with nursing actions to increase the survival of patients victims of CPA.
\end{abstract}

Keywords: Heart arrest; Cardiopulmonary resuscitation; Nursing; Life support care.

\section{Resumen}

Objetivo: producir una tecnología de asistencia para el equipo de enfermería para la detección de CPA e inicio temprano de maniobras de RCP. Metodología: Se trata de un estudio metodológico, desarrollado en tres etapas: Paso 1 - Definición del alcance, realizado en un hospital acreditado como Centro de Alta Complejidad en Oncología. La investigación se realizó con enfermeras, enfermeras residentes y técnicos de enfermería, el Paso 2 - Encuesta bibliográfica - mostró una escasez de producciones sobre el tema abordado, lo que justifica la creación del instrumento descrito en este estudio y Paso 3 - Desarrollo - El diagrama de flujo. Resultado: Se obtuvieron respuestas que permitieron comparar antes y después de la aplicación de un instrumento de recolección creado por los propios autores y que condujo a la creación de la tecnología. Conclusión: La creación del diagrama de flujo como tecnología asistencial para sistematizar las acciones de enfermería en la clínica, permitió ofrecer asistencia presencial de manera clara y concisa, con acciones de enfermería para incrementar la supervivencia de los pacientes víctimas de CPA.

Palabras clave: Paro cardíaco; Reanimación cardiopulmonar; Enfermería; Cuidados para prolongación de la vida.

\section{Introdução}

A Parada Cardiorrespiratória (PCR) é a representação da interrupção súbita da circulação sanguínea e mecanismo ventilatório de um indivíduo. Antigamente a PCR estava muito associada a morte iminente em decorrência da precariedade de conhecimento em ralação à situação, no entanto, nos dias atuais, com a qualificação adequada, a sobrevida chega a $70 \%$ (Souza et al., 2021).

No Brasil, destaca-se que aproximadamente há 200.000 casos por ano e metade dessas ocorrências acontecem no 
ambiente intra-hospitalar. Algumas causas existentes para ocasionar uma PCR são as doenças cardiovasculares que estão entre os danos de maior incidência na população brasileira e diversos fatores como as condições clínicas do paciente (Assalin et al., 2019).

O bom prognóstico e a sobrevida das pessoas que sofrem uma PCR se associam com a intervenção rápida, oportuna e de qualidade com que as manobras de recuperação são iniciadas (Pettersson et al., 2018). A atuação eficaz e livre de danos ao paciente durante a PCR contribuem significativa para a sobrevida dos pacientes, já que cada minuto de parada diminui as chances de sobrevivência de 7\% a 10\% (Santos et al., 2018).

Diante desse cenário, reconhece-se que a enfermagem desempenha papel fundamental no atendimento às vítimas de PCR, desenvolvendo ações desde o reconhecimento do caso, participação nas manobras de reanimação e organização das ações e serviços. Assim, é importante que a equipe de enfermagem esteja bem treinada e capacitada para lidar com situações críticas como a PCR e desenvolver uma assistência de qualidade diante de ocasiões adversas (Taveira, 2018).

Outrossim, destaca-se que é importante que o enfermeiro e a equipe de enfermagem estejam preparados para lidar com situações-problemas como a PCR e detenha competência e habilidade para prestar atendimento adequado, já que a eminencia de uma PCR no ambiente hospitalar é tida como um desafio para a enfermagem e que carece de uma atuação rápida, segura e de qualidade (Marques et al., 2016).

Contata-se que a enfermagem é a profissão que por vezes está à frente do atendimento às vítimas de PCR, sendo importante mediar o conhecimento da equipe, identificando lacunas no conhecimento e justificando a necessidade de educação continuada na perspectiva de promover uma assistência integral, resolutiva e segura qualidade do cuidado e satisfação do usuário, família e comunidade (Espíndola et al., 2017).

O objetivo deste estudo é construir uma tecnologia assistencial para a equipe de enfermagem para detecção de PCR e início precoce de manobras de RCP. Para propiciar o desenvolvimento desta pesquisa, elaborou-se a seguinte questão norteadora: Como uma tecnologia educativa, voltada para a sistematização das ações da equipe de enfermagem frente a uma PCR, pode melhorar o serviço e quais dificuldades dessa equipe?

\section{Metodologia}

Trata-se de um estudo metodológico (Pollit \& Beck, 2019), que visa a proposição de uma tecnologia em forma de fluxograma, para auxiliar na sistematização da assistência de enfermagem em situações de PCR em uma clínica cirúrgica. Para tanto, elaborou-se um percurso metodológico próprio para o desenvolvimento da tecnologia.

\section{Etapa 1 - Definição do escopo (Análise e desenho)}

O estudo foi realizado em um hospital que atende demanda encaminhada pela rede básica, ambulatorial e hospitalar, de todo o Estado do Pará, destinando 100\% (cem por cento) de sua capacidade instalada a pacientes do SUS. O Hospital é credenciado como Centro de Alta Complexidade em Oncologia (CACON) e Hospital de Ensino pelo Ministério da Saúde (MS) e vem se especializando cada vez mais no tratamento multidisciplinar das doenças crônico-degenerativas.

Descreve-se mais precisamente que o local de desenvolvimento do estudo foi uma clínica do hospital com voltagem cirúrgica referência nas especialidades de urologia, mastologia e cirurgia torácica. A referida clínica é composta por 29 leitos rotativos de internação pré e pós-cirurgia.

Para a realização deste estudo, elencou-se como critérios de inclusão enfermeiros, técnicos de enfermagem e residentes de enfermagem, maiores de 18 anos, estarem no posto de enfermagem no momento da aplicação dos formulários de coleta de dado e de ambos os gêneros. Para tanto, excluíram-se outros profissionais que não os citados; os impossibilitados de responder aos instrumentos do estudo por quaisquer motivos; os que não estivessem presente durante a coleta do estudo, já que 
não fora feito a tentativa de comunicação via e-mail ou telefone e os que preencheram os formulários incorretamente após três tentativas, visando não influenciar nos dados dos participantes.

A pesquisa se desenvolveu com os profissionais de saúde da enfermagem (enfermeiros, enfermeiros residentes e técnicos de enfermagem), de unidade de internação cirúrgica, de ambos os gêneros dos turnos matutino, vespertino e noturno, em uma estimativa de 27 participantes, sendo pelo turno matutino 2 enfermeiros e 7 técnicos, vespertino 2 enfermeiros e 6 técnicos, noturno 2 enfermeiros e 6 técnicos e mais 2 enfermeiros plantonistas.

O método de amostragem foi por conveniência mediante a acessibilidade dos participantes, pois essa técnica possibilita captar uma amostra da população que seja acessível e os participantes da pesquisa estão prontamente disponíveis e não porque foram selecionadas por critérios estatísticos (Freitag, 2018).

\section{Etapa 2 - Levantamento bibliográfico}

$\mathrm{Na}$ etapa de levantamento bibliográfico, optou-se por realizar uma Revisão Integrativa da Literatura (RIL), pois a mesma possibilita reconhecer as lacunas no conhecimento a respeito de um tema e assim contribuir para o desenvolvimento deste estudo (Ursi \& Gavão, 2006).

Assim, foi realizada uma busca nas seguintes bases de dados: Literatura Latino-Americana e do Caribe em Ciências da Saúde (LILACS) e os recursos internacionais da biblioteca eletrônica The Scientific Electronic Library Online (SciELO) e Literatura Internacional em Ciências da Saúde (PUBMED). Os descritores utilizados foram: "parada cardiorrespiratória", "reanimação cardiopulmonar", "enfermagem" e "suporte avançado de vida", no caso da base de dados da PUBMED os descritores foram usados em inglês: "cardiorespiratory arrest", "cardiopulmonary resuscitation", "nursing", "advanced life support".

O operador booleano "AND" foi utilizado junto ao descritor "enfermagem/nursing" na barra de busca de modo a associá-lo com os outros descritores.

Dos artigos encontrados e filtrados após a leitura dos títulos, apenas um (100\%) apresentou a temática similar com a do presente estudo. Tratava-se de uma pesquisa/estudo quantitativo, descritivo e de delineamento transversal com o objetivo de avaliar o conhecimento dos profissionais de enfermagem que atuam no setor de hemodiálise acerca do atendimento à PCR em adultos, suporte básico e avançado de vida cardiovascular, com base nas diretrizes de RCP da American Heart Association (AHA) do ano de 2020 (Santos et al., 2017).

A realização da RIL demonstra uma escassez de produções acerca do tema abordado e corrobora para justificar a criação do instrumento descrito neste estudo, conferindo suporte e embasamento científico para sistematizar as ações da enfermagem mediante uma PCR.

\section{Etapa 3 - Desenvolvimento}

Para a coleta de dados, adotou-se um questionário que contou com questões objetivas, semiestruturadas, embasadas nas diretrizes da AHA de 2020 (AHA, 2020), divididas em duas etapas, sendo a primeira para caracterizar o perfil sociodemográfico e laboral que contemplou gênero, categoria profissional e tempo de trabalho. A segunda etapa se encarregou de verificar a experiencia profissional e levantar o conhecimento apresentado pelos profissionais em relação a PCR. O instrumento é uma adaptação de um instrumento de coleta (Bellan et al., 2010) em que foram realizas perguntas organizadas em sequência lógica e compatível com as recomendações da AHA para a PCR no SAV em Cardiologia (ACLS).

Os dados foram transferidos para planilhas eletrônicas e tabulados com auxílio do Programa Microsoft Excel 2016. A análise foi por meio de estatística descritiva simples, exibida em frequência absoluta e porcentagens, organizadas em forma de tabela e gráficos através do programa Excel 2016 e discutidas de acordo com o tema em questão. 
O projeto da pesquisa foi encaminhado para avaliação e apreciação do Comitê de Ética em Pesquisa em Seres Humanos (CEP) do Hospital Ophir Loyola (HOL). Após autorização do projeto pelo comitê este obteve a anuência com CAAE: 42971021.2.0000.5550 e Número do Parecer: 4.575.742. Após isso, fora realizado o primeiro contato dos pesquisadores com os profissionais da clínica para realizar as entrevistas com os enfermeiros em horários e dias préestabelecidos pela mesma.

A abordagem dos profissionais foi realizada durante o turno de trabalho, no qual fora elucidados os objetivos do estudo e realizado o convite para participar da pesquisa. Aos que aceitaram, foi entregue o TCLE para que fosse assinado e o participante ficava com uma das copias do instrumento para que pudesse responder e logo posteriormente devolver preenchido. A coleta foi realizada nos três turnos de funcionamento da clínica durante dois meses, de agosto a setembro de 2021.

Construiu-se a tecnologia voltada para as demandas identificadas nas respostas dos participantes, em formato de fluxograma. Este formato de tecnologia leve-dura fora escolhido pelos profissionais durante a aplicação do questionário. Por fim, fora realizado um treinamento para o uso da tecnologia criada e que contou com auxílio de um caso clínico fictício para propiciar a realização da ação. Durante este momento também fora aplicado novamente o questionário contendo as perguntas para verificar se houve mudança no conhecimento em relação ao tema proposto.

\section{Resultados e Discussão}

A Tabela 1 a seguir apresenta informações no que se refere a categoria profissional de cada entrevistado, o sexo e o tempo de formação dos participantes do estudo que foram obtidos por meio da aplicação do formulário de identificação sociodemográfico.

Tabela 1: Caracterização sociodemográfica e laboral dos trabalhadores de enfermagem hospitalar. Belém, Brasil, 2021.

\begin{tabular}{|c|c|c|c|}
\hline \multirow[t]{2}{*}{ Categoria Profissional } & \multicolumn{2}{|c|}{ Sexo } & \multirow[t]{2}{*}{ Tempo de formação } \\
\hline & Masculino & Feminino & \\
\hline Enfermeiro & 0 & 4 & 02-20 Anos \\
\hline Técnico em enfermagem & 4 & 11 & $04-32$ anos \\
\hline Residente de enfermagem & 1 & 0 & 06 meses \\
\hline
\end{tabular}

De acordo com a Tabela 1, constatou-se a presença significativa do sexo feminino, com prevalência de $75 \%$ do total dos participantes. Já em relação a categoria profissional, os técnicos de enfermagem foram o público mais presente no resultado deste estudo. Além disso, evidenciou-se que o tempo de formação foi a variável que mais obteve diferença entre os dados dos participantes, como variação de 06 meses a 32 anos de formação. Após a coleta de dados por meio dos questionários, utilizou-se figuras para expressar graficamente os resultados obtidos com a aplicação dos questionários e da educação em saúde após o primeiro contato com os participantes.

A Figura 1 apresenta as respostas dos participantes em relação à pergunta contida no questionário sobre se os profissionais já haviam recebido algum tipo de treinamento de Suporte Avançado de Vida e feito uma correlação entre as respostas antes e depois da educação continuada realizada pelos pesquisadores junto a eles. 
Figura 1. Respostas antes e depois da educação continuada dos trabalhadores de enfermagem hospitalar sobre treinamento em SAV durante PCR. Belém, Brasil, 2021.
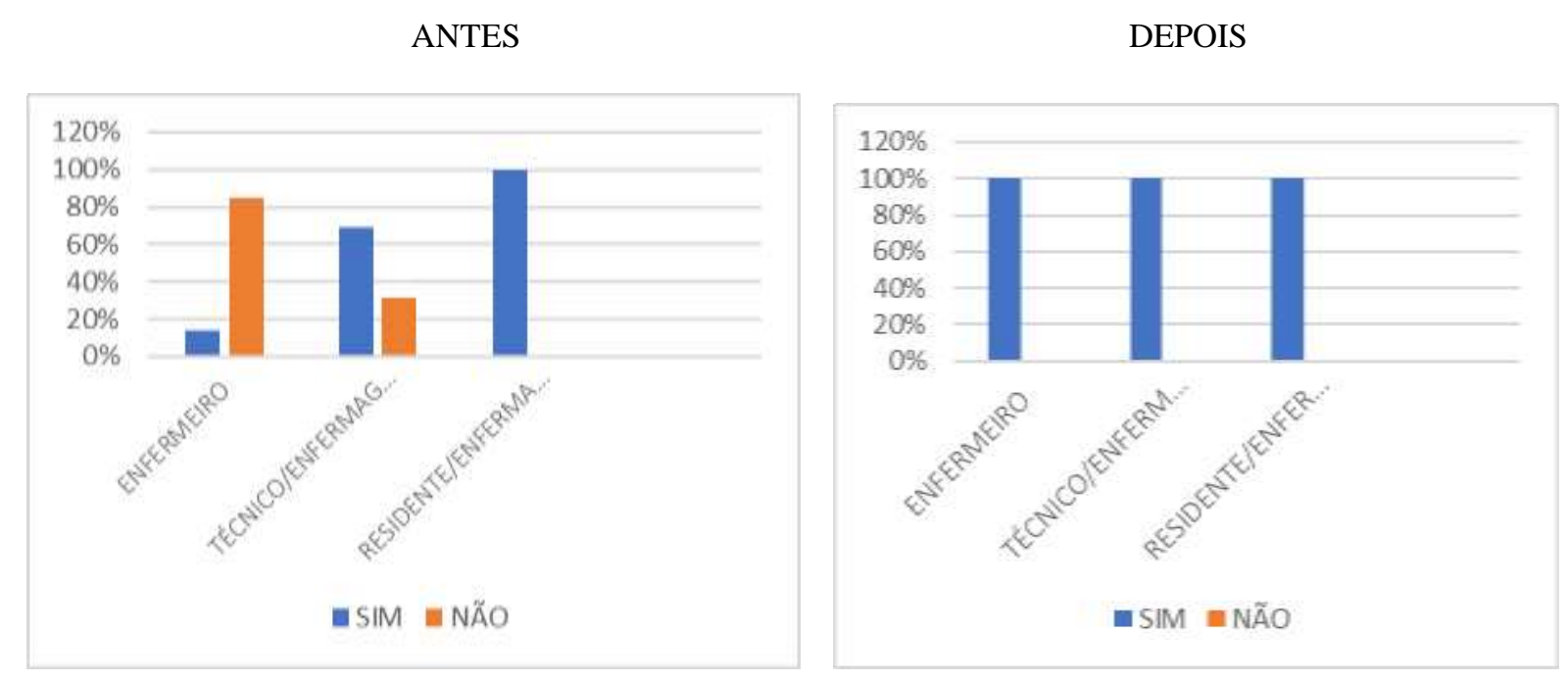

Fonte: Dado dos autores.

Com base nas informações dos gráficos acima foi possível verificar que $69 \%$ dos técnicos de enfermagem já haviam recebido treinamento sobre $\mathrm{SAV}$, tendo algum conhecimento a respeito da temática. Contrapondo-se a este cenário, observouse que apenas $14 \%$ dos enfermeiros já haviam sido treinados sobre SAV, o que chama atenção para essa informação, já que a instituição é de nível de alta complexidade e necessita ter profissionais bem capacitados sobre diversas situações. Por fim, observou-se que o residente de enfermagem já havia tido contato com treinamento em SAV.

Apresenta-se, ainda os dados referentes as respostas dadas depois da educação continuada referente ao recebimento de treinamento sobre SAV, e pode-se observar que os participantes de maneira geral consideraram a capacitação realizada como resposta afirmativa para a pergunta: "você já teve algum tipo de treinamento sobre Suporte Avançado de Vida?", sendo possível observar diferença nos gráficos antes e depois.

Em relação a Figura 2, perguntou-se aos participantes se eles conheciam a escala de Mews e também fora feito a comparação das respostas antes e depois da realização da educação continuada sobre SAV. 
Figura 2 - Respostas antes e depois da educação continuada dos trabalhadores de enfermagem hospitalar em SAV durante a PCR sobre o conhecimento da Escala de Mews. Belém, Brasil, 2021.

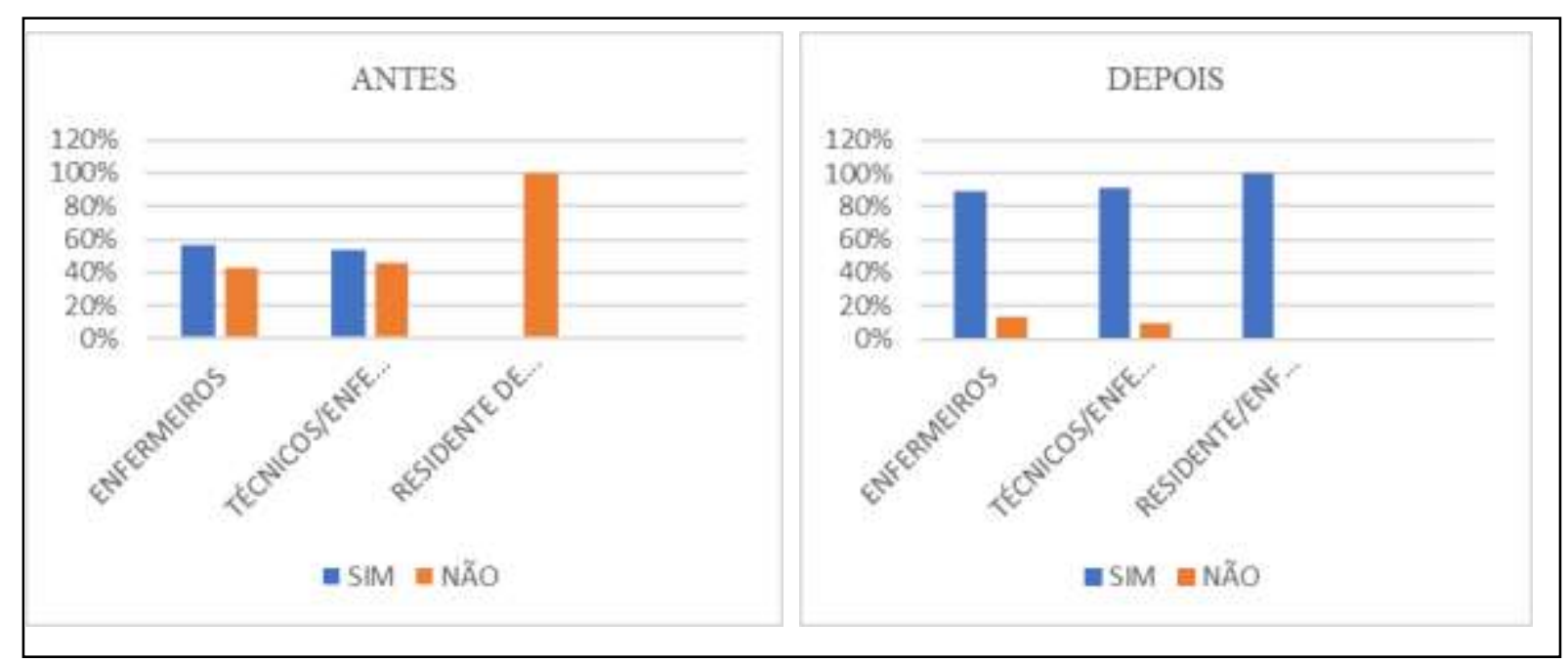

Fonte: Dado dos autores.

Ao analisar os dados da figura, observa-se que apenas 54\% dos técnicos de enfermagem sabiam ou tinham algum conhecimento sobre a Escala de Mews (Modified early warning system), enquanto que dos enfermeiros a porcentagem ficou em 57\%, não distante da porcentagem dos técnicos, e o residente de enfermagem afirmou também não conhecer o instrumento, o que demonstra uma falta de materiais para embasar e dar suporte clínico aos profissionais durante a tomada de decisão e propiciar uma assistência rápida e segura.

Percebeu-se, ainda sobre essa questão, uma divergência nos gráficos dos enfermeiros e técnicos de enfermagem em relação as respostas antes e depois, pois mesmo após a educação continuada, ainda pode-se observar que alguns participantes afirmaram não conhecer sobre a Escala em questão, o que pode ser justificado por uma abordagem frágil por parte dos pesquisadores, a qual não conseguiu alcançar o conhecimento dos profissionais ou pela própria logística da rotina de trabalho, haja vista que as entrevista se deram na ocorrência do desenvolvimento da assistência. Ainda assim, os resultados foram satisfatórios, pois a maioria conseguiu ter aproximação com a escala e perceber o seu funcionamento mediante uma PCR.

Apresenta-se na Figura 3 as respostas dos participantes sobre a conduta que teriam caso se deparassem com uma situação de PCR e fora avaliado as respostas antes e depois da educação continuada realizada pelos pesquisadores. 
Figura 3 - Respostas antes e depois da educação continuada dos trabalhadores de enfermagem hospitalar em SAV durante a PCR sobre a conduta mediante uma PCR pelos. Belém, Brasil, 2021.

\begin{tabular}{|c|c|c|c|c|}
\hline \multicolumn{5}{|c|}{ ANTES } \\
\hline Categoria & $\begin{array}{l}\text { Alternativa A - } \\
\text { Aciona o médico }\end{array}$ & $\begin{array}{l}\text { Alternativa B - } \\
\text { Aciona a equipe } \\
\text { da emergência }\end{array}$ & $\begin{array}{l}\quad \text { Alternativa C - } \\
\text { Inicia a } \\
\text { compressão } \\
\text { torácica e solicita } \\
\text { que alguém da } \\
\text { equipe acione o } \\
\text { médico }\end{array}$ & $\begin{array}{l}\text { Alternativa D - } \\
\text { Aciona a equipe } \\
\text { da Unidade de } \\
\text { Terapia Intensiva }\end{array}$ \\
\hline Enfermeiro & $14 \%$ & $28 \%$ & $57 \%$ & $0 \%$ \\
\hline $\begin{array}{l}\text { Técnico de } \\
\text { enfermagem }\end{array}$ & $38 \%$ & $15 \%$ & $46 \%$ & $0 \%$ \\
\hline $\begin{array}{l}\text { Residente de } \\
\text { enfermagem }\end{array}$ & $0 \%$ & $0 \%$ & $100 \%$ & $0 \%$ \\
\hline Categoria & $\begin{array}{l}\text { Alternativa A - } \\
\text { Aciona o médico }\end{array}$ & $\begin{array}{l}\text { DEPOIS } \\
\text { Alternativa B - } \\
\text { Aciona a equipe } \\
\text { da emergência }\end{array}$ & $\begin{array}{l}\quad \text { Alternativa C - } \\
\text { Inicia a } \\
\text { compressão } \\
\text { torácica e solicita } \\
\text { que alguém da } \\
\text { equipe acione o } \\
\text { médico }\end{array}$ & $\begin{array}{l}\text { Alternativa D - } \\
\text { Aciona a equipe } \\
\text { da Unidade de } \\
\text { Terapia Intensiva }\end{array}$ \\
\hline Enfermeiro & $0 \%$ & $10 \%$ & $90 \%$ & $0 \%$ \\
\hline $\begin{array}{l}\text { Técnico de } \\
\text { enfermagem }\end{array}$ & $0 \%$ & $0 \%$ & $100 \%$ & $0 \%$ \\
\hline $\begin{array}{l}\text { Residente de } \\
\text { enfermagem }\end{array}$ & $0 \%$ & $0 \%$ & $100 \%$ & $0 \%$ \\
\hline
\end{tabular}

Fonte: Dado dos autores.

Averiguou-se com as respostas da Figura 3 que antes da educação continuada os técnicos, enfermeiros e o residente de enfermagem, em sua maioria, conseguiram chegar à resposta correta, representada pela alternativa "D - Iniciar compressões torácicas e solicitar que alguém acione o médico", porém verifica-se que houve um grande percentual de erros que demonstram deficiência em relação a temática.

Agruparam-se as respostas dos participantes após a realização da educação continuada e foi possível perceber a persistência de respostas errôneas por porte dos enfermeiros em relação a temática, na qual mesmo depois da aproximação dos entrevistados com o tema, os profissionais de nível superior ainda assinalaram a alternativa "B - Acionar a equipe de emergência" como a resposta correta. Ao analisar as respostas da equipe técnica, pode-se considerar um resultado positivo da educação continuada, pois $100 \%$ dos participantes responderam de forma correta o item "B".

Emergiu-se com a figura 4 as respostas dos profissionais sobre as habilidades em identificar uma PCR, avaliando sinais e sintomas característicos que exigem uma RCP de qualidade. Além disso, a figura também permitiu evidenciar e comparar as respostas antes e após a realização da educação continuada sobre SAV. 
Figura 4 - Resposta antes e depois da educação continuada em SAV durante PCR dos trabalhadores de enfermagem hospitalar sobre a habilidade profissional em reconhecer e intervir em uma possível PCR. Belém, Brasil, 2021.

\begin{tabular}{|c|c|c|c|c|}
\hline \multicolumn{5}{|c|}{ ANTES } \\
\hline Categoria & $\begin{array}{l}\text { Alternativa A - } \\
\text { Ausência de } \\
\text { movimentos } \\
\text { respiratórios }\end{array}$ & $\begin{array}{l}\text { Alternativa B - } \\
\text { Inconsciência }\end{array}$ & $\begin{array}{l}\text { Alternativa C - } \\
\text { Ausência de } \\
\text { sinais de } \\
\text { circulação }\end{array}$ & $\begin{array}{l}\text { Alternativa D - } \\
\text { Todas as } \\
\text { alternativas acima }\end{array}$ \\
\hline Enfermeiro & $14 \%$ & $0 \%$ & $14 \%$ & $71,40 \%$ \\
\hline $\begin{array}{c}\text { Técnico de } \\
\text { enfermagem }\end{array}$ & $15 \%$ & $0 \%$ & $0 \%$ & $85 \%$ \\
\hline $\begin{array}{l}\text { Residente de } \\
\text { enfermagem }\end{array}$ & $0 \%$ & $0 \%$ & $0 \%$ & $100 \%$ \\
\hline \multicolumn{5}{|c|}{ DEPOIS } \\
\hline & $\begin{array}{l}\text { Alternativa A - } \\
\text { Ausência de } \\
\text { movimentos } \\
\text { respiratórios }\end{array}$ & $\begin{array}{l}\text { Alternativa B - } \\
\text { Inconsciência }\end{array}$ & $\begin{array}{l}\text { Alternativa C - } \\
\text { Ausência de } \\
\text { sinais de } \\
\text { circulação }\end{array}$ & $\begin{array}{c}\text { Alternativa D - } \\
\text { Todas as } \\
\text { alternativas acima }\end{array}$ \\
\hline Enfermeiro & $0 \%$ & $0 \%$ & $0 \%$ & $100 \%$ \\
\hline $\begin{array}{c}\text { Técnico de } \\
\text { enfermagem }\end{array}$ & $\%$ & $9 \%$ & $0 \%$ & $91,0 \%$ \\
\hline Residente de & $0 \%$ & $0 \%$ & $0 \%$ & $100 \%$ \\
\hline
\end{tabular}

Fonte: Dado dos autores.

Foi observado nesta questão que a maioria de técnicos e enfermeiros (mais de $60 \%$ em cada categoria) responderam saber reconhecer de imediato uma possível vítima de PCR por meio de sinais e sintomas característicos, logo entende-se que mesmo sem uma adequada capacitação teórica, os participantes conseguem identificar e prestar alguma assistência ao paciente pela vivência da rotina do serviço.

Detalha-se por meio dos gráficos, que houve uma melhora significativa das respostas em relação a identificação de uma PCR após a educação continuada sobre SAV em que também fora abordar a identificação do usuário vítima de PCR, entendendo-se que o treinamento foi bastante proveitoso e com rendimento satisfatório, a porcentagem dos gráficos de enfermeiros chegou a $100 \%$ enquanto que o de técnicos alcançou a casa dos $90 \%$, pode inferir que a questão foi respondida com mais segurança após treinamento. 
Figura 5 - Respostas antes e depois da educação continuada em SAV durante PCR pelos trabalhadores de enfermagem hospitalar sobre o conhecimento da cadeia de sobrevivência intra-hospitalar. Belém, Brasil, 2021.

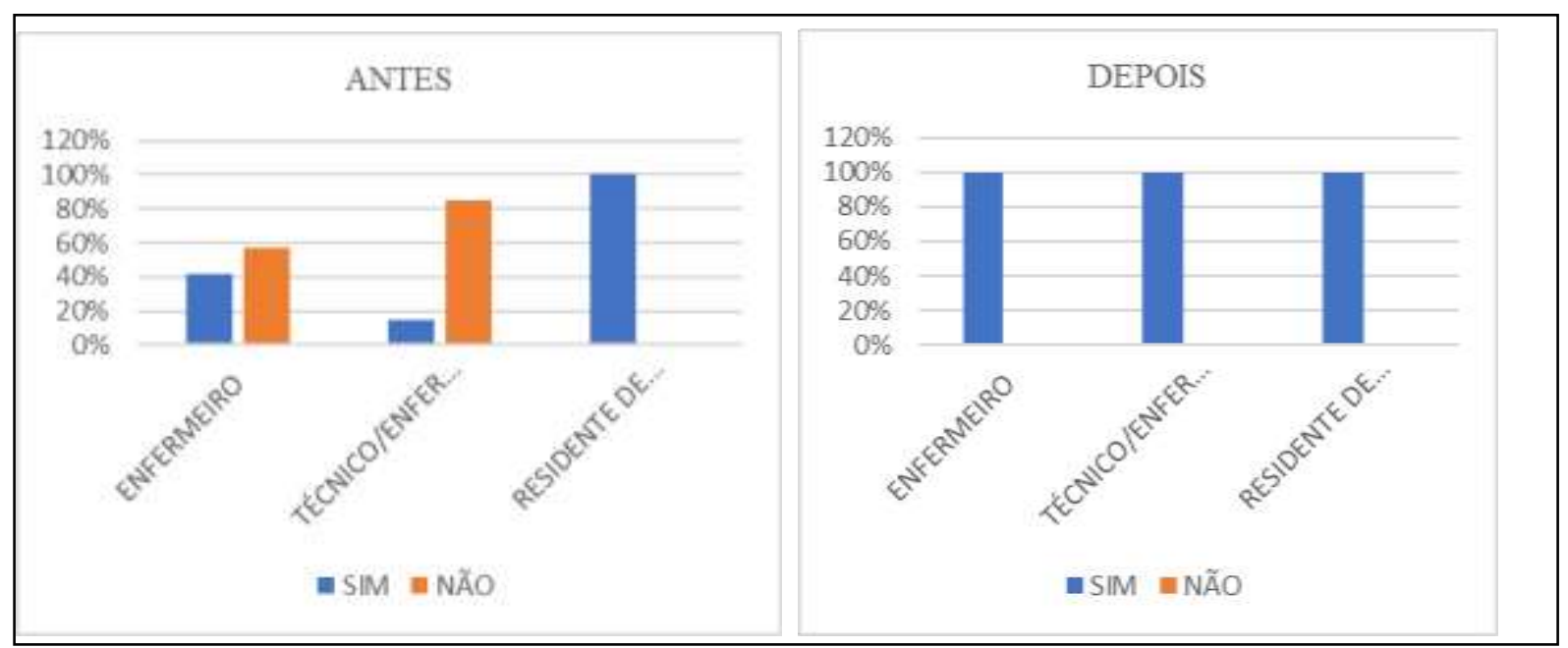

Fonte: Dado dos autores.

Pontua-se que $85 \%$ dos técnicos de enfermagem antes do educação continuada responderam saber o que é a cadeia de sobrevivência e como funciona, enquanto que entre os enfermeiros apenas 57\% responderam saber do que se tratava, chamado a atenção dos autores para este item, haja vista que esse conhecimento é de suma importância para a organização da equipe e dos fluxos durante uma PCR, a fim de realizar uma assistência de qualidade com segurança, eficácia e isenta de erros que causam malefícios aos pacientes.

Verificou-se, porém que após a participação na educação continuada, as questões referentes à cadeia de sobrevivência intra-hospitalar durante uma PCR foram respondidas de forma satisfatória, resultado evidenciado pela comparação entre os gráficos da Figura 5, em que todos os profissionais alcançaram a margem percentual de 100\% nas respostas positivas.

Por fim, apresenta-se como resultado da Tabela 2, as respostas dos profissionais após a realização da educação continuada, ao ser aplicado um questionário que buscava identificar qual o interesse dos profissionais pelo tipo de material a ser construído e deixado na clínica para servir de suporte técnico-científico para lidar com uma vítima de PCR.

Tabela 2 - Resposta dos trabalhadores de enfermagem hospitalar sobre qual melhor tecnologia a ser construída e deixada na clínica. Belém, Brasil, 2021.

\begin{tabular}{|c|c|c|c|c|c|}
\hline Categoria & Banner & Fluxograma & Pôster & $\begin{array}{c}\text { Aplicativo de } \\
\text { celular }\end{array}$ & $\begin{array}{l}\text { Quadro } \\
\text { Branco }\end{array}$ \\
\hline Enfermeiro & $0 \%$ & $100 \%$ & $0 \%$ & $0 \%$ & $0 \%$ \\
\hline $\begin{array}{l}\text { Técnico de } \\
\text { enfermagem }\end{array}$ & $15 \%$ & $46 \%$ & $8 \%$ & $15 \%$ & $15 \%$ \\
\hline $\begin{array}{l}\text { Residente de } \\
\text { enfermagem }\end{array}$ & $0 \%$ & $100 \%$ & $0 \%$ & $0 \%$ & $0 \%$ \\
\hline
\end{tabular}

Fonte: Dado dos autores.

Esta última pergunta serviu como base para os pesquisadores identificarem qual a melhor tecnologia leve-dura para ser deixada na clínica como suporte para os profissionais durante a assistência ao usuário vítima de PCR na clínica. Apresentase como resultado da questão o Fluxograma como o instrumento mais indicados pelos entrevistados.

Essa etapa foi muito importante para a construção da tecnologia, pois contou com a participação dos voluntários para desenvolver o instrumento. O corpus e o conteúdo do material foram construídos mediante as respostas dos profissionais e 
pelas lacunas no conhecimento observadas, agregando conhecimento à deficiência e necessidade elencada. Além disso, foi possível contar com objetivos claros e concisos, norteando o design instrucional e auxiliar na avaliação do processo educativo.

A Figura 6 a seguir demonstra o resultado da criação do fluxograma criado pelos pesquisadores e deixado na clínica para demonstrar o fluxo do trabalho a seguir seguido durante uma PCR nos intermédios da clínica.

Figura 6 - Organização da equipe na RCP - Belém, Brasil, 2021.

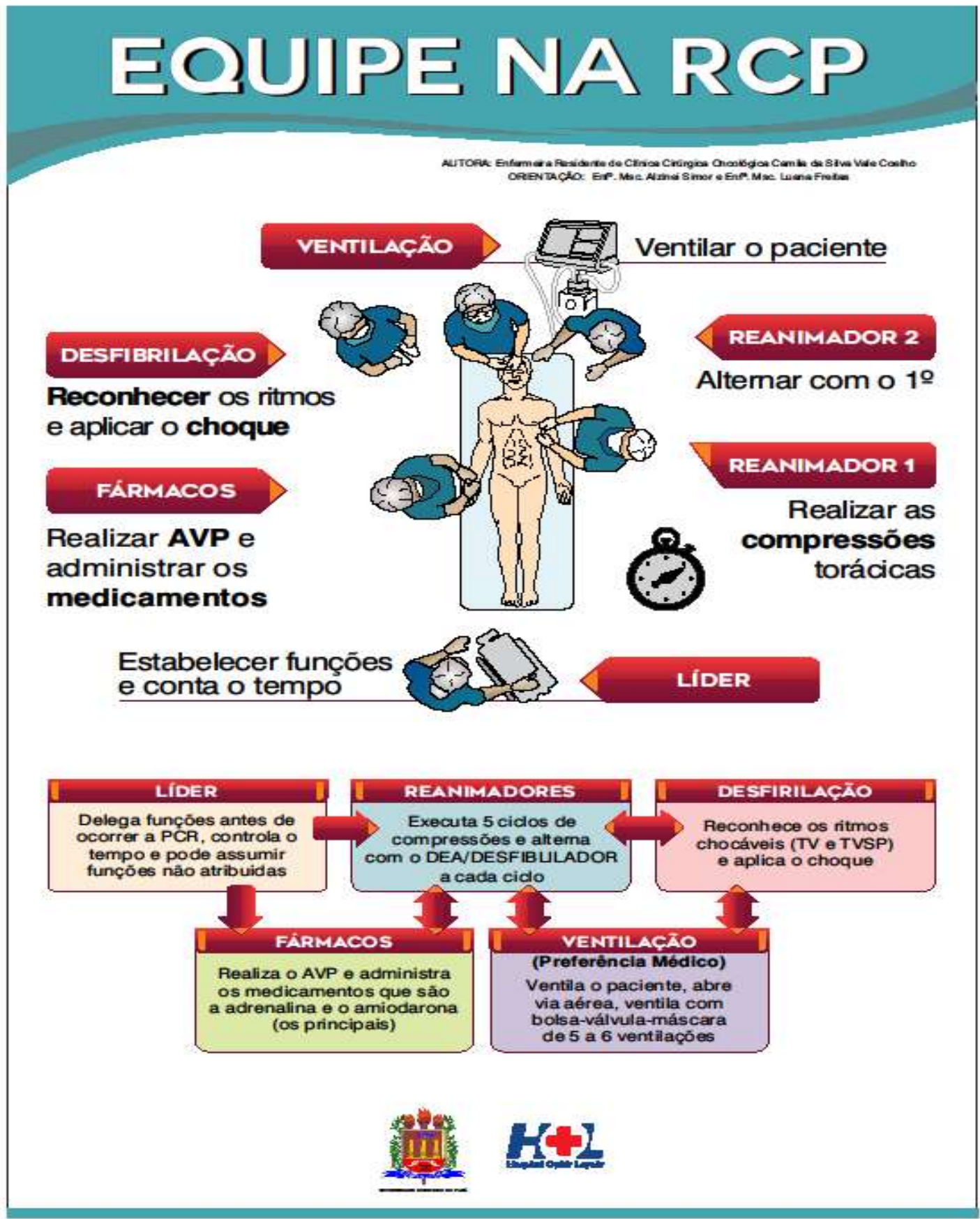

Fonte: Dado dos autores.

Constata-se em um estudo analítico e transversal realizado em um hospital universitário em um município do Estado de São Paulo resultado semelhante ao encontrado nesta pesquisa, haja vista que o estudo em questão demonstra que a caracterização sociodemográfica e laboral dos trabalhadores de enfermagem do hospital em que ocorreu a pesquisa é 
representada sumariamente por mulheres $(79,4 \%),(52,2 \%)$ eram técnicos de enfermagem e com tempo de trabalho considerado alto (Silveira et al., 2021).

O resultado da Figura 1 vem de encontro com um estudo que buscou identificar o conhecimento da equipe de enfermagem em um hospital no norte do estado do Espírito Santo sobre SAV revelou que 88,33\% dos profissionais também não tinham contato prévio com qualquer tipo de educação em saúde sobre SAV (Lopes \& Nogueira, 2021).

Ressalta-se, porém, que a realização da educação continuada realizada posteriormente com os profissionais foi, para alguns, o primeiro contato dos usuários com questões de SAV. Evidencia-se em um estudo uma melhora abrupta do conhecimento dos profissionais da enfermagem após o treinamento em PCR (Bellan et al., 2010).

Uma pesquisa observacional desenvolvida no Japão demonstrou que indivíduos bem capacitados têm maiores habilidades e capacidade de realizar uma boa RCP em comparação com profissionais não treinados, os quais podem apresentar temor pela situação, medo de errar e o sentimento de vergonha por não saber realizar uma assistência mediante uma situação de PCR (Tanigawa et al., 2011).

Ao analisar os resultados da figura 2, constatou-se que a maioria dos profissionais não detinham conhecimento sobre a escala Mews, o que explana uma situação complicada, por se tratar de um hospital de alta complexidade e que atende pacientes geralmente em situação oncológica crítica em transoperatório. Considera-se que a utilização da escala propicia a redução da morte súbita de pacientes, diminui o risco de evento de PCR e a dependência de cuidados intensivos (Lopes \& Vieira, 2021).

A escala Mews fornece subsídios para avaliar quatro sinais vitais, temperatura, pressão arterial, frequência cardíaca e permite uma avaliação rápida do nível de consciência como a situação de alerta, verbalização, dor e responsividade. Considerase ainda que a utilização desse instrumento é de fácil manuseio e aplicação, permite a comunicação efetiva e padronizada e a tomada de decisão em conjunto pela equipe, além de poder ser realizado por qualquer profissional desde que treinado (Balshi et al., 2020).

Os resultados deste estudo se igualam a uma pesquisa realizada com enfermeiros atuantes em uma Unidade de Terapia Intensiva (UTI) em que $73,91 \%$ dos profissionais não deram $100 \%$ de resposta considerada correta sobre quanto ao reconhecimento dos sinais de uma PCR (Moura et al., 2019). Porém, um estudo realizado no Estado de São Paulo mostrou ao questionar enfermeiros sobre os sinais clínicos de uma PCR 100\% dos profissionais responderam satisfatoriamente os itens da pesquisa, corroborando com os dados após o desenvolvimento da educação continuada (Lima \& Invenção, 2017).

Desvela-se nos resultados deste estudo que antes da realização da educação continuada sobre SAV na PCR os profissionais responderam insatisfatoriamente os dados do questionário, o que traz à luz da evidencia uma realidade assustadora, pois a sobrevida de uma pessoa vítima de PCR é de 75\% durante os primeiros quatro minutos, $15 \%$ do quarto ao décimo segundo minuto e 5\% após 15 minutos e isso se forem bem feitas e de forma imediata (Alves et al., 2013).

Esse resultado é semelhante ao encontrado em um estudo realizado com profissionais de enfermagem do setor de urgência de um hospital universitário na cidade de Petrolina no Pernambuco em que apontou que 78,26\% das respostas dos profissionais foram consideradas parcialmente corretas sobre a conduta a ser tomada imediatamente ao identificar uma PCR (Moura et al., 2019).

Os resultados sobre o conhecimento da cadeia de sobrevivência intra-hospitalar foi um dos itens que mais obteve respostas negativas antes da realização da educação continuada. Esses dados se assemelham ao de um estudo realizado em Londrina-PR, no qual 85,2\% dos responderam não ter tido qualquer tipo de treinamento a respeito do ACLS em que consta informações detalhadas sobre a cadeia de sobrevivência intra-hospitalar (Prestes \& Menetrier, 2017).

É importante destacar que o desconhecimento de tais condutas são considerados problemas graves para uma assistência de qualidade, ocasionando sérias complicações aos usuários vítimas de PCR. Constata-se que o bom prognóstico 
diante de uma PCR se relaciona com um atendimento de qualidade realizado pelos profissionais, que deve contar com competências e habilidades técnicas e científicas proporcionada pela capacitação profissional (Silva et al., 2018).

Outrossim, demonstrou-se com os resultados deste estudo que os participantes optaram pela construção de um fluxograma como proposta de tecnologia a ser deixada na clínica para servir como suporte na durante uma situação de PCR intra-hospitalar e que necessita de SAV. Em um estudo de pesquisa-ação realizado no município de São José-SC por enfermeiros demonstrou que a escolha do fluxograma se deu por este instrumento utilizar simbologias geométricas para descrever as etapas de um fluxo de forma suscinta e autoexplicativa do processo laboral (Silva et al., 2020).

O fluxograma descreve de forma objetiva e clara um fluxo de trabalho, auxilia no desenvolvimento de novos processos ou melhora os processos já existentes, elimina o retrabalho e torna ínfimo o desperdício de tempo, recursos humano e materiais (Silveira, 2006). De forma pratica, o fluxograma é a representação da rotina de um fluxo em que se é definido o destino de sua aplicação, etapas com início, meio e fim e avaliação se espelham a realidade, pois irá utilizar símbolos para facilitar o entendimento das pessoas que terão contato com o instrumento (Mello, 2008).

\section{Considerações Finais}

A criação do fluxograma como tecnologia educativa para sistematizar ações de enfermagem na clínica, possibilitou oferecer de forma clara, concisa, direta e com o mínimo de erros possíveis a sistematização da assistência no local, com ações de enfermagem para aumentar a sobrevida de pacientes vítimas de PCR e qualificar o processo assistencial.

A iniciativa e o esforço em criar uma tecnologia em contribuição com a equipe para contribuir com a assistência, bem como organizar o fluxo de trabalho (PCR), orientar intervenções quanto a identificação precoce de uma PCR e as condutas a serem tomadas no ambiente intra-hospitalar, auxiliar os trabalhadores na tomada de decisão e padronizar os procedimentos.

A criação do fluxograma, além de melhorar prática comum nos serviços dos profissionais, minimiza a realização de procedimentos que envolvam riscos para os funcionários. Todavia, o monitoramento e acompanhamento de como entrevistados estão lidando com a tecnologia deve ser realizado rotineiramente, para acompanhamento da qualidade das ações realizadas durante o atendimento que necessite das informações contidas no fluxograma, incentivando o aprimoramento técnico e a autonomia na tomada de condutas apesar das limitações que por ventura podem ser encontradas.

Essa experiencia demonstrou que é possível implementar tecnologias que contribuam para sistematizar assistências quando realizada em consonância com as demandas do público-alvo. A definição de estratégias conjuntas, possibilitada pelos resultados encontrados nas respostas dos atores locais, possibilitou a sensibilização dos atores envolvidos já que podem se deparar com um instrumento fruto de seus anseios.

O estudo possibilita perceber que a inquietação, a continuidade, a articulação e a evolução das práticas baseadas em evidencia de forma técnica-científica quando direcionadas para propiciar a qualidade da assistência de enfermagem podem ser consideradas como experiencias exitosas no ambiento da profissão.

Considera-se ainda imprescindível que outros profissionais direcionem seus estudos em uma linha de pensamento que se iguale â este estudo, pois ao se tratar de um ambiente hospitalar, as condutas são dadas mediantes uma equipe multiprofissional e de forma interprofissional, sendo necessário a padronização das ações, assim como também demonstrou a necessidade de capacitações rotineiras dos profissionais.

\section{Agradecimentos}

Ao Programa de Residência Uniprofissional de atenção ao câncer da Universidade do Estado do Pará e ao Hospital Hophir Loyola. 


\section{Referências}

American Heart Association. (2015). Destaques da American Heart Association 2015: atualização das diretrizes de RCP e ACE. Dallas, TX: American Heart Association.

Assalin, A. C., de Souza, A. C., de Souza, A. R., de Oliveira, L. N., Grazziano, E. da S., \& Machado, R. C. (2019). Programa de Formación Teórico/Práctico En Loco de Enfermería Sobre las Operaciones en Reanimación Cardiopulmonar Básica. Revista De Pesquisa: Cuidado é Fundamental, 11(2), 495-501. http://ciberindex.com/c/ps/P112033.

Balshi, A. N., Huwait, B. M., Noor, A. S. N., Alharthy, A. M., Madi, A. F., Ramadan, O. E., \& Aletreby, W. T. (2020). Modified Early Warning Score as a predictor of intensive care unit readmission within 48 hours: a retrospective observational study. Revista Brasileira de Terapia Intensiva, $32,301-307$.

Bellan, M. C., Araújo, I. I. M., \& Araújo, S. (2010). Capacitação teórica do enfermeiro para o atendimento da parada cardiorrespiratória. Revista Brasileira de Enfermagem, 63, 1019-1027.

Espindola, M. C. M., Espindola, M. M. M., Moura, L. T. R. \& Lacerda, L. C. A. (2017). Parada cardiorrespiratória: conhecimento dos profissionais de enfermagem em uma unidade de terapia intensiva. Revista de Enfermagem UFPE on line, 11(7), 2773-2778.

Freitag, R. M. K. (2018). Amostras sociolinguísticas: probabilísticas ou por conveniência? Revista de estudos da linguagem, 26(2), 667-686.

Lima, A. R., \& Invenção, A. D. S. S. (2017). Atuação do enfermeiro na parada cardiorrespiratória em uma unidade de pronto atendimento (UPA). UNILUS Ensino e Pesquisa, 14(36), 272-279.

Lopes, N. R., \& Vieira, T. S. (2021). A aplicação da escala mews na residência de clínica médica: um relato de experiência. Brazilian Journal of Development, 7(11), 106335-106341.

Lopes, A. P. O., \& Nogueira, G. B. (2021). O conhecimento do enfermeiro e sua atuação no atendimento intra-hospitalar à vítima de parada cardiorrespiratória. Revista Eletrônica Acervo Saúde, 13(5), e7520. https://doi.org/10.25248/reas.e7520.2021

Marques, P. F., Torres, M. T., de Sousa, M. A., \& Costa, V. S. (2016). Produção de enfermagem sobre parada cardio respiratória: revisão integrativa. Revista Baiana de Saúde Pública, 40(3).

Moura, J. G., de Brito, M. D. P. S., Rocha, G. D. O. S., \& de Moura, L. T. R. (2019). The Knowledge and Acting of a Nursing Team from a Sector of Cardiorespiratory Arrest Urgent Care/Conhecimento e Atuação da Equipe de Enfermagem de um Setor de Urgência no Evento Parada Cardiorrespiratória. Revista de Pesquisa Cuidado é Fundamental Online, 11(3), 634-640.

Mello, A.E.N.S. (2008). Aplicação do mapeamento de processos e da simulação no desenvolvimento de projetos de processos produtivos (dissertação). Itajubá (MG): Universidade Federal de Itajubá.

Pettersen, T. R., Mårtensson, J., Axelsson, Å., Jørgensen, M., Strömberg, A., Thompson, D. R. \& Norekvål, T. M. (2018). European cardiovascular nurses’ and allied professionals' knowledge and practical skills regarding cardiopulmonary resuscitation. European Journal of Cardiovascular Nursing, 17(4), 336344 .

Prestes, J. N., \& Menetrier, J. V. (2017). Conhecimento da equipe de enfermagem de uma unidade de terapia intensiva adulta sobre a parada cardiorrespiratória. Biosaúde, 19(1), 1-11.

Polit, D. F., \& Beck, C. T. (2019). Fundamentos de pesquisa em enfermagem: avaliação de evidências para a prática da enfermagem. Artmed Editora.

Santos, M. S., Toledo, L. V., Alves, K. R., Santana, M. M. R., Ribeiro, L., \& Diaz, F. B. B. S (2019). Conhecimento da equipe de enfermagem do setor de hemodiálise sobre o atendimento a parada cardiorrespiratória. HU Revista, 43(4), 375-381. https://doi.org/10.34019/1982-8047.2017.v43.2924

Santos, P. D. B., Santos Júnior, E. B. \& de Sousa Borges Pinheiro, L. (2018). Cardiorespiratory arrest: surveillance, prevention and care after PCR. Revista de Pesquisa: Cuidado e Fundamental, 10(2).

Silva, L. G. S., Castro, M. N., \& Andrade, V. F. (2018). Atuação do enfermeiro frente à parada cardiorrespiratória no ambiente intra-hospitalar. Journal of Health Connections, $3(2)$

Silveira, R. C. P., Ribeiro, I. K. S, \& Mininel, V. A. (2021). Qualidade de vida, perfil sociodemografico e laboral da equipe de enfermagem de um hospital universitário. Enfermería Actual en Costa Rica, (41).

Silva, V. B. D. S., Backes, M. T. S., Mello, J. F. D., Magagnin, J. S., Brasil, J. M., Silva, C. I. D., \& Santos, C. D. (2020). Construção coletiva de um fluxograma para acompanhamento das gestantes com sífilis no município de são josé-sc. Cogitare enferm, e65361-e65361.

Silveira, C. B. Fluxograma de processo: o que é, como elaborar e benefícios

Sousa, M., Mota, R., Gomes, A., de Lima, R., de Oliveira, S. \& Freire de Freitas, R. (2021). Atendimento ao adulto em parada cardiorrespiratória: intervenção educativa para estudantes leigos. Enfermagem em Foco, 12(2).

Tanigawa, K., Iwami, T., Nishiyama, C., Nonogi, H., \& Kawamura, T. (2011). Are trained individuals more likely to perform bystander CPR? An observational study. Resuscitation, 82(5), 523-528.

Taveira, R. P. C. (2018). Atuação do enfermeiro na equipe de saúde durante parada cardiorrespiratória em Unidade de Terapia Intensiva Pediátrica: proposta de protocolo.

Ursi, E. S., \& Gavão, C. M. (2006). Prevenção de lesões de pele no perioperatório: revisão integrativa da literatura. Revista Latino-Americana de Enfermagem, 14, 124-131. 